Article

\title{
Mg-Fe Layered Double Hydroxides Enhance Surfactin Production in Bacterial Cells
}

\author{
Pei-Hsin Chang ${ }^{1}$, Si-Yu Li ${ }^{1,2}$, Tzong-Yuan Juang ${ }^{3, *}$ and Yung-Chuan Liu ${ }^{1, *}$ \\ 1 Department of Chemical Engineering, National Chung Hsing University, 145 Xingda Road, \\ South District, Taichung 40227, Taiwan \\ 2 Innovation and Development Center of Sustainable Agriculture, NCHU, Taichung 40227, Taiwan \\ 3 Department of Cosmeceutics, China Medical University, Taichung 40402, Taiwan \\ * Correspondence: tyjuang@mail.cmu.edu.tw (T.-Y.J.); ycliu@dragon.nchu.edu.tw (Y.-C.L.)
}

Received: 20 June 2019; Accepted: 11 July 2019; Published: 12 July 2019

check for updates

\begin{abstract}
In this study, four additives-montmorillonite, activated carbon, and the layered double hydroxides (LDHs), $\mathrm{Mg}_{2} \mathrm{Fe}-\mathrm{LDH}$ and $\mathrm{Mg}_{2} \mathrm{Al}-\mathrm{LDH}$ - were tested for their ability to promote surfactin production in a Bacillus subtilis ATCC 21332 culture. Among these tested materials, the addition of $4 \mathrm{~g} / \mathrm{L}$ of the $\mathrm{Mg}-\mathrm{Fe} \mathrm{LDH}$, which featured an $\mathrm{Mg} / \mathrm{Fe}$ molar ratio of 2:1, produced the highest surfactin yield of $5280 \mathrm{mg} / \mathrm{L}$. During the time course of B. subtilis cultivation with the added LDH, two phases of cell growth were evident: Growth and decay. In the growth phase, the cells grew slowly and secreted a high amount of surfactin; in the decay phase, the cells degraded rapidly. The production in the presence of the $\mathrm{Mg}_{2} \mathrm{Fe}-\mathrm{LDH}$ had three characteristics: (i) High surfactin production at low biomass, indicating a high specific surfactin yield of $3.19 \mathrm{~g} / \mathrm{g}$ DCW; (ii) rapid surfactin production within $24 \mathrm{~h}$, inferring remarkably high productivity $(4660 \mathrm{mg} / \mathrm{L} / \mathrm{d})$; and (iii) a lower carbon source flux to biomass, suggesting an efficient carbon flux to surfactin, giving a high carbon yield of $52.8 \%$. The addition of $\mathrm{Mg}_{2} \mathrm{Fe}-\mathrm{LDH}$ is an effective means of enhancing surfactin production, with many potential applications and future industrial scale-up.
\end{abstract}

Keywords: Bacillus subtilis; surfactin; quantitative analysis; fermentation; growth phase; layered double hydroxides

\section{Introduction}

Biosurfactants are amphipathic molecules produced by microorganisms [1-3] with the capability of decreasing surface and interfacial tension [4]. Depending on their chemical composition and their producing organism, biosurfactants can possess high biodegradability, low toxicity, ecological acceptability, and high efficiency. Accordingly, they have been investigated as possible alternatives to chemical surfactants $[5,6]$. Bacillus spp., bacterial strains of complicated physiological diversity, can be used to produce many bioactive peptides with potential biotechnological and biopharmaceutical applications. Among these peptides, the lipopeptides that feature an alkyl group and a circular peptide group are the most popular biosurfactants [7]; these materials include surfactins [8-10], iturins [11,12], and fengycins [13].

The surfactin produced by B. subtilis is one of the strongest biosurfactants available [7]. Its chemical composition is that of a cyclic lipopeptide (comprising seven amino acids) with a 12 to 19-carbon atom hydrophobic fatty acid chain [14]. Surfactin can lower the surface tension of water to $27 \mathrm{mN} / \mathrm{m}$ even when its concentration is as low as $0.005 \%[7,10,15,16]$, suggesting its great potential applicability. Nevertheless, the high expense and low yield of surfactin production have limited its commercial use. Yeh et al. found that limiting the concentration of the carbon source (glucose) affected the surfactin production mediated by B. subtilis [17]. Davis et al. observed the highest production of surfactin when 
ammonium nitrate was the nitrogen source during B. subtilis cultivation in a defined medium [18]. Sen et al. noted that the ratio of Mn and Fe mineral salts in the medium was a factor affecting the production of surfactin [19]. Wei and Chu found that the yield of surfactin increased dramatically, over those obtained using genetic strains, when employing $0.01 \mathrm{mM} \mathrm{Mn}^{2+}$ [20]. Furthermore, Wei et al. employed an iron-enriched $\left(4 \mathrm{mM} \mathrm{Fe}^{2+}\right)$ minimal salt medium to produce $3000 \mathrm{mg} / \mathrm{L}$ of surfactin [21]. Moreover, some of these studies revealed that the addition of solid additives (e.g., activated carbon (AC) or expanded clay) could increase surfactin production significantly. For example, Yeh et al. added AC and increased the yield of surfactin to $3600 \mathrm{mg} / \mathrm{L}$ [17].

Layered double hydroxides (LDHs) —also known as anionic clays-comprise cationic brucite-like layers with exchangeable interlayer anions [22]. Because a positive ionic charge appears on the surface layer, many types of molecules can be intercalated into LDHs [23-27]. Several methods have been developed to widen the layered gallery, with globular macromolecules as intercalating agents [28,29]. Conterosito et al. intercalated various pharmaceutics drugs and cosmetic sunscreen into Mg-Al_LDH and $\mathrm{Zn}$-Al_LDH. They revealed that different bioactive molecules could interact with inorganic $\mathrm{LDH}$ and demonstrated the relationship between the molecular length and an enlarged interlayer spacing [30]. Toson et al. showed the intercalation of organic molecules into the LDH interlayer by the liquid-assisted grinding method. The intercalation mechanism for layer widening with intercalated organic molecules was investigated [31]. Choy et al. employed supramolecular inorganic species (e.g., nanoscale $\mathrm{Mg}-\mathrm{Al} \mathrm{LDH}$ ) as biomolecule reservoirs that could be used for gene and drug delivery [23,32]. Nevertheless, few studies have focused on using LDHs as additives for microbial cultivation. Kan et al. prepared $\mathrm{Mg}_{2} \mathrm{Al}-\mathrm{LDH}$ and investigated its effect as an additive on surfactin production and surfactin intercalation [33]. When considering the application of the surfactin-intercalated LDH as a slow release bio-pesticide, however, this aluminum salt was prohibited from field tests [34]. For agricultural applications, iron salts are generally considered less toxic. Therefore, in this present study, we prepared several Mg-Fe LDH derivatives with potentially greater practicality. We tested the effects of their addition on the production of surfactin from a $B$. subtilis culture. To our surprise, replacing the additive to $\mathrm{Mg}_{2} \mathrm{Fe}-\mathrm{LDH}$ had an extraordinary effect on the surfactin production. Accordingly, we examined various $\mathrm{Mg}_{n} \mathrm{Fe}-\mathrm{LDH}(\mathrm{n}=1,2,3)$ compositions and concentrations to determine the optimal conditions for surfactin production. In addition, we examined the time course of the production in the optimal culture. An extra low biomass of cells yielded the highest surfactin production. This result was quite different from that obtained after the addition of $\mathrm{Mg}_{2} \mathrm{Al}-\mathrm{LDH}$. Furthermore, we compared the effects of the LDHs with those of other additives (e.g., montmorillonite (MMT), AC), and determined the conditions for the highest production of surfactin through quantitative analysis. Herein, we also suggest possible reasons for the enhancement of surfactin production mediated by LDHs.

\section{Materials and Methods}

\subsection{Chemicals and Reagents}

$\mathrm{Al}\left(\mathrm{NO}_{3}\right)_{3} \cdot 9 \mathrm{H}_{2} \mathrm{O}, \mathrm{Fe}\left(\mathrm{NO}_{3}\right)_{3} \cdot 9 \mathrm{H}_{2} \mathrm{O}$, and $\mathrm{Mg}\left(\mathrm{NO}_{3}\right)_{2} \cdot 6 \mathrm{H}_{2} \mathrm{O}$ were purchased from SHOWA, USA. MMT was obtained from Alfa Aesar, USA. The AC was obtained from China Activated Carbon (Taipei, Taiwan); it had a diameter of 3 to $4 \mathrm{~mm}$, a height of $9 \mathrm{~mm}$, and a specific surface area of $1200 \mathrm{~m}^{2} / \mathrm{g}$, and was prepared from bituminous coal with an iodine number of $1150 \mathrm{mg} / \mathrm{g}$. Surfactin $(\geq 98 \%$, Sigma-Aldrich, Missouri, MO, USA) was used as the standard. All solvents and other chemicals were of analytical grade.

\subsection{Microorganisms and Culture Conditions}

The strain, B. subtilis ATCC 21332, was obtained from Professor Wei Yu-Hong of Yuan Ze University. This strain was kept on a nutrient-agar plate at $30{ }^{\circ} \mathrm{C}$. For cultivation, its seed medium comprised $1 \%$ glucose, $0.5 \%$ yeast extract, $1 \%$ peptone, and $1 \% \mathrm{NaCl}$. The seed culture was performed in Erlenmeyer flasks $(500 \mathrm{~mL})$ containing the seed medium $(100 \mathrm{~mL})$ inoculated with two loops of cells. 
The cultivation was conducted at $200 \mathrm{rpm}$ and $30^{\circ} \mathrm{C}$ for $12 \mathrm{~h}$. The main shake-flask culture was conducted in an Erlenmeyer flask $(500 \mathrm{~mL})$ containing the main medium $(100 \mathrm{~mL})$ comprising $10 \mathrm{~g} / \mathrm{L}$ sucrose, $5 \mathrm{~g} / \mathrm{L}\left(\mathrm{NH}_{4}\right)_{2} \mathrm{SO}_{4}, 5.67 \mathrm{~g} / \mathrm{L} \mathrm{Na} \mathrm{HPO}_{4}, 4.08 \mathrm{~g} / \mathrm{L} \mathrm{KH}_{2} \mathrm{PO}_{4}, 0.2 \mathrm{~g} / \mathrm{L} \mathrm{MgSO}{ }_{4} \cdot 7 \mathrm{H}_{2} \mathrm{O}$, and $0.57 \mathrm{~g} / \mathrm{L}$ $\mathrm{FeSO}_{4} \cdot 7 \mathrm{H}_{2} \mathrm{O}$. The media were sterilized $\left(121^{\circ} \mathrm{C}, 20 \mathrm{~min}\right)$; the carbon source was autoclaved separately. The medium $(90 \mathrm{~mL})$ was inoculated with the seed broth $(10 \mathrm{~mL})$. The flasks were incubated on a rotary shaker ( $200 \mathrm{rpm}, 30{ }^{\circ} \mathrm{C}, 5$ days). When testing additives, MMT, AC, and the prepared LDHs were added $(2 \mathrm{~g} / \mathrm{L})$ to the culture medium at the beginning of the culture process.

\section{3. $\mathrm{Mg}_{2} \mathrm{Al}-\mathrm{LDH}$ and $\mathrm{Mg}_{2} \mathrm{Fe}-\mathrm{LDH}$}

$\mathrm{Mg}_{2} \mathrm{Al}-\mathrm{NO}_{3}-\mathrm{LDH}$ and $\mathrm{Mg}_{2} \mathrm{Fe}-\mathrm{NO}_{3}-\mathrm{LDH}$ were prepared through co-precipitation, as described previously [27]. To prepare the $\mathrm{Mg}_{2} \mathrm{Al}-\mathrm{LDH}$ sample, $\mathrm{Mg}\left(\mathrm{NO}_{3}\right)_{2} \cdot 6 \mathrm{H}_{2} \mathrm{O}(120 \mathrm{~g})$ and $\mathrm{Al}\left(\mathrm{NO}_{3}\right)_{3} \cdot 9 \mathrm{H}_{2} \mathrm{O}$ $(90 \mathrm{~g})$ were dissolved in deionized $\mathrm{H}_{2} \mathrm{O}(1 \mathrm{~L})$. To prepare the $\mathrm{Mg}_{2} \mathrm{Fe}-\mathrm{LDH}$ sample, $\mathrm{Mg}\left(\mathrm{NO}_{3}\right)_{2} \cdot 6 \mathrm{H}_{2} \mathrm{O}$ $(169 \mathrm{~g})$ and $\mathrm{Fe}\left(\mathrm{NO}_{3}\right)_{3} \cdot 9 \mathrm{H}_{2} \mathrm{O}(134 \mathrm{~g})$ were mixed in deionized $\mathrm{H}_{2} \mathrm{O}(1 \mathrm{~L})$. To prepare samples with $\mathrm{Mg} / \mathrm{Fe}$ molar ratios of 1.0 and 3.0, appropriate amounts of $\mathrm{Mg}\left(\mathrm{NO}_{3}\right)_{2} \cdot 6 \mathrm{H}_{2} \mathrm{O}$ and $\mathrm{Fe}\left(\mathrm{NO}_{3}\right)_{3} \cdot 9 \mathrm{H}_{2} \mathrm{O}$ were used. Each aqueous solution was stirred vigorously at $80^{\circ} \mathrm{C}$ while purging with nitrogen gas. When preparing the $\mathrm{Mg}_{2} \mathrm{Al}-\mathrm{LDH}$ sample, the $\mathrm{pH}$ was maintained at $10 \pm 0.2$ by adding $4 \mathrm{~N} \mathrm{NaOH}$ in portions. For the $\mathrm{Mg}_{2} \mathrm{Fe}-\mathrm{NO}_{3}-\mathrm{LDH}$ sample, the $\mathrm{pH}$ was adjusted to $9.5 \pm 0.2$ by using a mixture of $\mathrm{NaOH}$ and $\mathrm{K}_{3}\left[\mathrm{Fe}(\mathrm{CN})_{6}\right]$, prepared based on the following compositions: $\left[\mathrm{OH}^{-}\right] /\left(\left[\mathrm{Mg}^{2+}\right]+\left[\mathrm{Fe}^{3+}\right]\right)=1.6$ and $\left[\left[\mathrm{Fe}(\mathrm{CN})_{6}\right]^{3-}\right] /\left[\mathrm{Fe}^{3+}\right]=3$. The suspension that formed was stirred at $80^{\circ} \mathrm{C}$ for $24 \mathrm{~h}$. The obtained precipitates - white $\mathrm{Mg}_{2} \mathrm{Al}-\mathrm{LDH}$ and dark-red $\mathrm{Mg}_{2} \mathrm{Fe}-\mathrm{LDH}$ - were filtered off and washed (deionized $\mathrm{H}_{2} \mathrm{O}$ ). The filtered cakes were lyophilized (freeze-drying). The dried LDHs were characterized using $\mathrm{x}$-ray diffraction (XRD; PANalytical, X'Pert PRO MRD, Almelo, Netherlands) and attenuated total reflectance Fourier transform infrared (ATR-FTIR) spectroscopy (Thermo Scientific, Nicolet iS50 FTIR, Madison, WI, USA).

\subsection{Quantitative Analysis}

To study the effects of LDH addition, the following quantitative terms are defined. The surfactin yield $(\mathrm{mg} / \mathrm{L})$ is expressed by the volumetric concentration. The carbon source yield is defined as:

$$
Y_{\frac{P}{S}}=\frac{\Delta P}{\Delta S}
$$

The productivity is defined as:

$$
\text { Productivity }=\frac{\Delta P}{\Delta t}
$$

The specific yield is defined as:

$$
Y_{\frac{P}{X}}=\frac{\Delta P}{\Delta X}
$$

where $P$ represents the surfactin concentration, $S$ is the carbon source concentration, $X$ is the concentration of biomass dried cells, and $t$ is the duration of cultivation. All concentrations are expressed herein on a volumetric basis.

\subsection{Assays}

The surfactin concentration was measured using a modified approach called salt-assisted homogeneous liquid-liquid extraction via high-performance liquid chromatography (HPLC) [33,35]. The culture broth $(1 \mathrm{~mL})$ was subjected to a centrifugation $\left(3200 \mathrm{~g}, 3 \mathrm{~min}, 4^{\circ} \mathrm{C}\right)$ to remove the solid pellets. The supernatant was mixed with $\mathrm{MeCN}(0.5 \mathrm{~mL})$ and ammonium sulfate $(0.8 \mathrm{~g})$ and subjected to vigorous stirring for $1 \mathrm{~min}$, and then centrifuged $(3200 \mathrm{~g}, 3 \mathrm{~min})$. The supernatant was filtered $(0.22 \mu \mathrm{m})$ to obtain the sample for injection. HPLC analysis was performed under the following conditions: A reversed-phase C-18A column $(5 \mathrm{~mm}, 18 \mathrm{~mm} \times 100 \mathrm{~mm}$ BDS-Hypersil, Thermo Fisher Scientific, Waltham, MA, USA); a mobile phase comprising $\mathrm{CF}_{3} \mathrm{CO}_{2} \mathrm{H}, \mathrm{MeCN}$, and deionized $\mathrm{H}_{2} \mathrm{O}$ 
(0.1:400:100); a flow rate of $1.0 \mathrm{~mL} / \mathrm{min}$; an injection sample volume of $20 \mu \mathrm{L}$; and a UV-Vis detector (JASCO, Tokyo, Japan) operated at $220 \mathrm{~nm}$. A standard curve was constructed using a freshly prepared solution of surfactin (Sigma). The chromatogram of the standard (supplemental Figure S1) revealed various ratios of the surfactin isoforms A-F. The surfactin produced using B. subtilis ATCC 21332 featured the same surfactin isoforms A-F at various ratios. In the surfactin assay, the whole isoforms were measured and added up for quantitative calculation. To analyze the cells' dried weight (CDW), $5 \mathrm{~mL}$ of the broth sample was subjected to centrifugation $(12,000 \mathrm{~g}, 10 \mathrm{~min})$ to obtain a pellet. Distilled $\mathrm{H}_{2} \mathrm{O}(5 \mathrm{~mL})$ was added to the pellet; after adjusting to $\mathrm{pH} 2.0$, the sample was vigorously stirred ( $\left.1 \mathrm{~min}\right)$. The mixture was centrifuged $(12,000 \mathrm{~g}, 5 \mathrm{~min})$. The pellet obtained was dissolved in distilled $\mathrm{H}_{2} \mathrm{O}$ $(5 \mathrm{~mL})$; the $\mathrm{pH}$ was adjusted to 7.0 and the mixture was again subjected to centrifugation. The obtained pellet was washed with distilled $\mathrm{H}_{2} \mathrm{O}(2 \times 5 \mathrm{~mL})$, dried $\left(80^{\circ} \mathrm{C}, 12 \mathrm{~h}\right)$, and then weighed. The basal spacing of the LDH was determined using a Shimadzu SD-D1 X-ray diffractometer with a Cu target (scanning rate: $\left.1^{\circ} / \mathrm{min}\right)$. The basal spacing was estimated using the Bragg equation $(n \lambda=2 d \sin \theta)$.

\subsection{Statistical Analysis}

Multiple flasks were run concurrently. Three flasks were employed each time for daily sampling. Each data point is expressed as a mean plus standard deviation. The Tukey test was applied for the comparison of results $(p \leq 0.05)$.

\section{Results and Discussion}

\subsection{Preparation of $\mathrm{MgFe}-\mathrm{LDH}$}

The addition of a small quantity of a solid carrier (AC or expanded clay) has been claimed as an effective approach toward increasing surfactin production [17]. LDHs are layered anionic exchange substances that have been intercalated with various macromolecules for the purpose of their slow release [36,37]. The addition of $\mathrm{Mg}_{2} \mathrm{Al}-\mathrm{LDH} \mathrm{LDH}$ to a surfactin production fermentation system involving B. subtilis incubation revealed that surfactin could indeed intercalate into the LDH layer gallery to form a surfactin-LDH complex; this phenomenon occurred with a significant increase in the production of surfactin [33]. In consideration of a slow-release composite for agricultural use, $\mathrm{Mg}_{2} \mathrm{Al}-\mathrm{LDH}$ would be inappropriate for field trials. For this study, therefore, we prepared $\mathrm{Mg}_{2} \mathrm{Fe}-\mathrm{LDH}$ instead. We examined the effect of adding this iron salt LDH to B. subtilis cultivation to study whether it, too, would promote surfactin production. The prepared $\mathrm{Mg}_{2} \mathrm{Fe}-\mathrm{LDH}$ was subjected to XRD and ATR-FTIR spectroscopic analysis. These analyses revealed an $\mathrm{Mg}_{2} \mathrm{Fe}-\mathrm{LDH}$ layer spacing of $7.8 \AA$ at a value of $2 \theta$ of $11.3^{\circ}$, derived from the calculation of Bragg's equation (Figure 1a), and a typical adsorption peak $\left(1381 \mathrm{~cm}^{-1}\right)$ for $\mathrm{NO}_{3}^{-}$anions within the prepared LDH (data not shown). In addition, to confirm the interaction between $\mathrm{LDH}$ and bacterial cells, the LDH after the cultivation was collected and subjected to XRD analysis. The result in Figure $1 \mathrm{~b}$ shows that the collected LDH did vary its $2 \theta$ from the original $11.3^{\circ}$ to $8.3^{\circ}$, indicating a d-spacing of $10.8 \AA$. The original XRD peak with a d-spacing of $7.8 \AA$ completely disappeared. The enlarged spacing was likely due to the LDH interaction with surfactin molecules. The isoelectric point (IEP) of surfactin is around $\mathrm{pH} 5$, and the fermentation process while applying LDH to the cultivation was around $\mathrm{pH}$ 7.4. The $\mathrm{pH}$ higher than the IEP would allow the surfactin to possess a negative charge, giving the chance of anion exchange for LDH intercalation. Besides, the interlayer spacing expansion of LDH might be ascribed not only to the surface interaction of surfactin intercalation but also the combination of water and other anion molecules in the culture medium into the $\mathrm{Mg}_{2} \mathrm{Fe}-\mathrm{LDH}$ interlayer. 


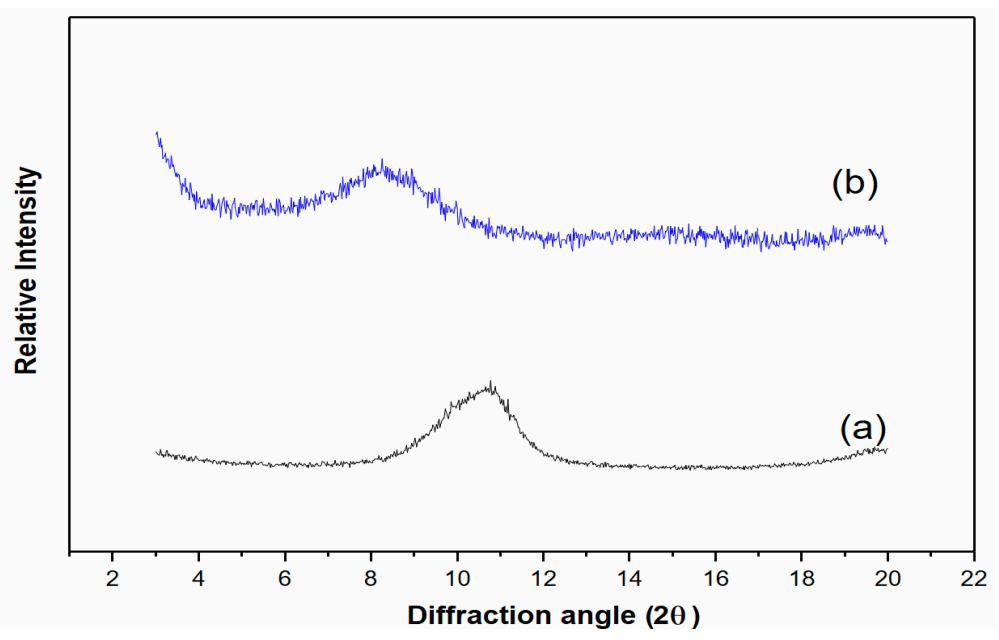

Figure 1. XRD pattern of (a) pristine $\mathrm{Mg}_{2} \mathrm{Fe}-\mathrm{LDH}$ and (b) $\mathrm{Mg}_{2} \mathrm{Fe}-\mathrm{LDH}$ collected after fermentation.

\subsection{Effect of Solid Additives on Surfactin Production}

As reported previously, the addition of some solid additives can enhance surfactin production [17]. For this present study, four solid additives-MMT, AC, and two LDHs-were prepared and added respectively to the $B$. subtilis culture medium; the medium prepared without any additives was used as the control during the five-day fermentation. The surfactin production increased when the culture medium contained each of these solid additives, relative to the control. The addition of MMT, AC, and the two LDHs (2 $\mathrm{g} / \mathrm{L})$ resulted in surfactin yields that had increased by 2.0-, 3.0-, 3.8-, and 4.5-fold, respectively, when compared with the control (Figure 2). It is noteworthy that the AC with the alkaline characterization might lead to surfactin linearization and surfactin binding on the AC surface, which may be an underestimation of the actual production. Thus, the LDHs were the most effective carriers for enhanced surfactin production in a culture of B. subtilis ATCC 21332. Furthermore, the amount of surfactin produced in the presence of $\mathrm{Mg}_{2} \mathrm{Fe}-\mathrm{LDH}$ was more than that produced in the presence of $\mathrm{Mg}_{2} \mathrm{Al}-\mathrm{LDH}$. Indeed, $\mathrm{Mg}_{2} \mathrm{Fe}-\mathrm{LDH}$ had an extraordinary stimulatory effect on promoting surfactin production.

\subsection{Effect of $M g F e-L D H$ Composition on Surfactin Production}

To study the effect of the $\mathrm{Mg} / \mathrm{Fe}$ molar ratio on surfactin production, $\mathrm{LDHs}$ were prepared with Mg:Fe molar ratios of 1:1, 2:1, and 3:1 and added into B. subtilis cultivation. The concentrations of the additive ranged from 1 to $6 \mathrm{~g} / \mathrm{L}$ in the fermentation medium. The cultivation was performed for 5 days. Figure 3 reveals that the $\mathrm{LDH}$ prepared with a Mg:Fe molar ratio of 2:1 had the greatest effect at promoting surfactin production. In general, LDHs possessing different ratios of divalent and trivalent metal ions possess different types of positively charged sheets and different layer dimensions in their resulting layered structures [38-41]. In the brucite-like layers of an $\mathrm{LDH}$, a fraction of the divalent metal ions is replaced by trivalent metal ions, with the molar ratio of $\mathrm{M}^{3+}:\left(\mathrm{M}^{3+}+\mathrm{M}^{2+}\right)(x)$ normally positioned between 0.2 and 0.4 [24,42]. In this present study, an Mg:Fe ratio of 2:1 $(x=0.33)$ had the best effect on improving surfactin production. Thus, it appears that the layer size associated with the positively charged sheets of the $\mathrm{Mg}_{2} \mathrm{Fe}-\mathrm{LDH}$ structure had the strongest stimulatory effect on the cells. 


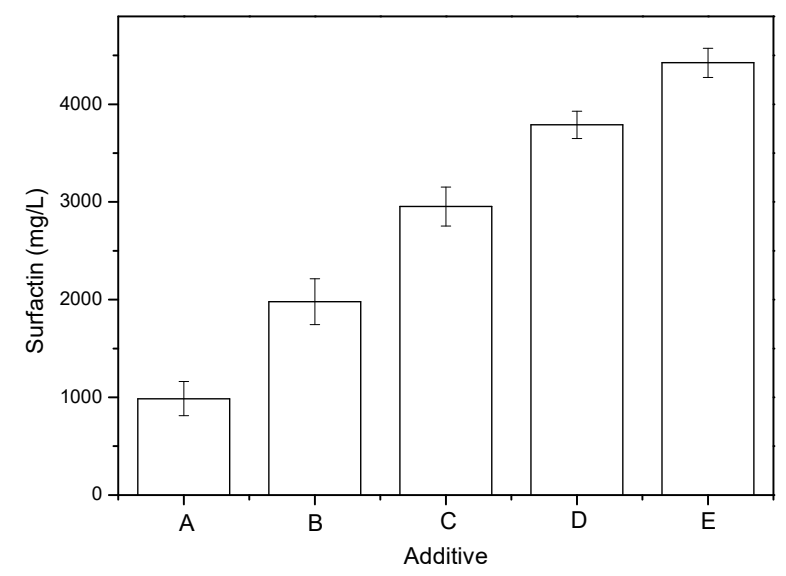

Figure 2. Effects of solid additives on surfactin yield in B. subtilis ATCC 21332 cultivation in a 5-day fermentation: (A) none; (B) MMT; (C) AC; (D) $\mathrm{Mg}_{2} \mathrm{Al}-\mathrm{LDH}$; (E) $\mathrm{Mg}_{2} \mathrm{Fe}-\mathrm{LDH}$. The surfactin level in the supernatant of the broth was determined. Error bars indicate the standard deviations from three tests.

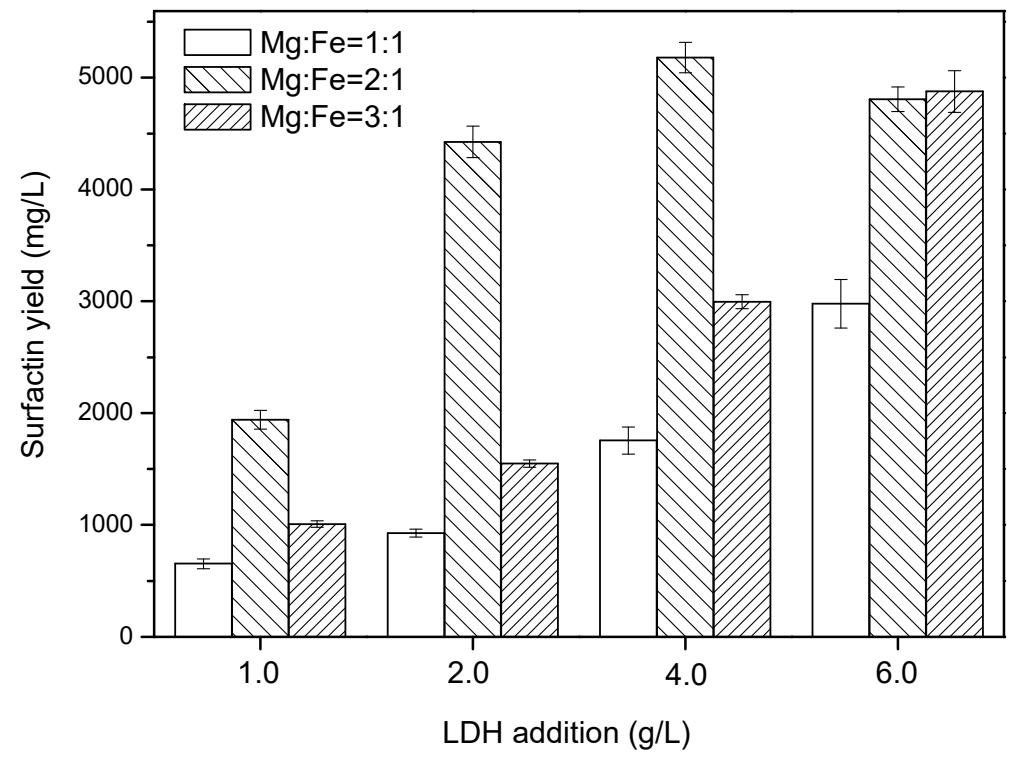

Figure 3. Effect of $\mathrm{Mg}_{2} \mathrm{Fe}-\mathrm{LDH}$ concentration $(1,2,4$, and $6 \mathrm{~g} / \mathrm{L})$ on the specific surfactin yield, where bars with different patterns represent various $\mathrm{Mg}^{2+}: \mathrm{Fe}^{3+}$ ratios: blank, 1:1; back slash, 2:1; slash, 3:1. Error bars indicate standard deviations from three tests.

\subsection{Time Course of Cultivation with LDH Addition}

To study the cell growth after adding $\mathrm{LDH}$, the time courses of the cultivation events performed with and without added LDH were recorded (Figure 4). Although the addition of $\mathrm{Mg}_{2} \mathrm{Fe}-\mathrm{LDH}$ promoted surfactin production, relative to that of the control, it was interesting to observe that the cell growth ended on the first day, where the amount of surfactin reached $4.8 \mathrm{~g} / \mathrm{L}$. In terms of product formation kinetics, this behavior was a clear growth-associated pattern: The cells grew and surfactin was produced. After day 1, the cells began to degrade in a decay phase, with the surfactin production decelerating. In contrast, the growth of cells was very rapid in the culture medium prepared without $\mathrm{LDH}$, but the level of surfactin production was very low. Thus, a slight inhibition of cell growth appeared to trigger the cells to secrete more surfactin. We suspect that the surfactin secreted by the cells performed a role as a protecting agent that kept the cells from coming into direct contact with the LDH. 


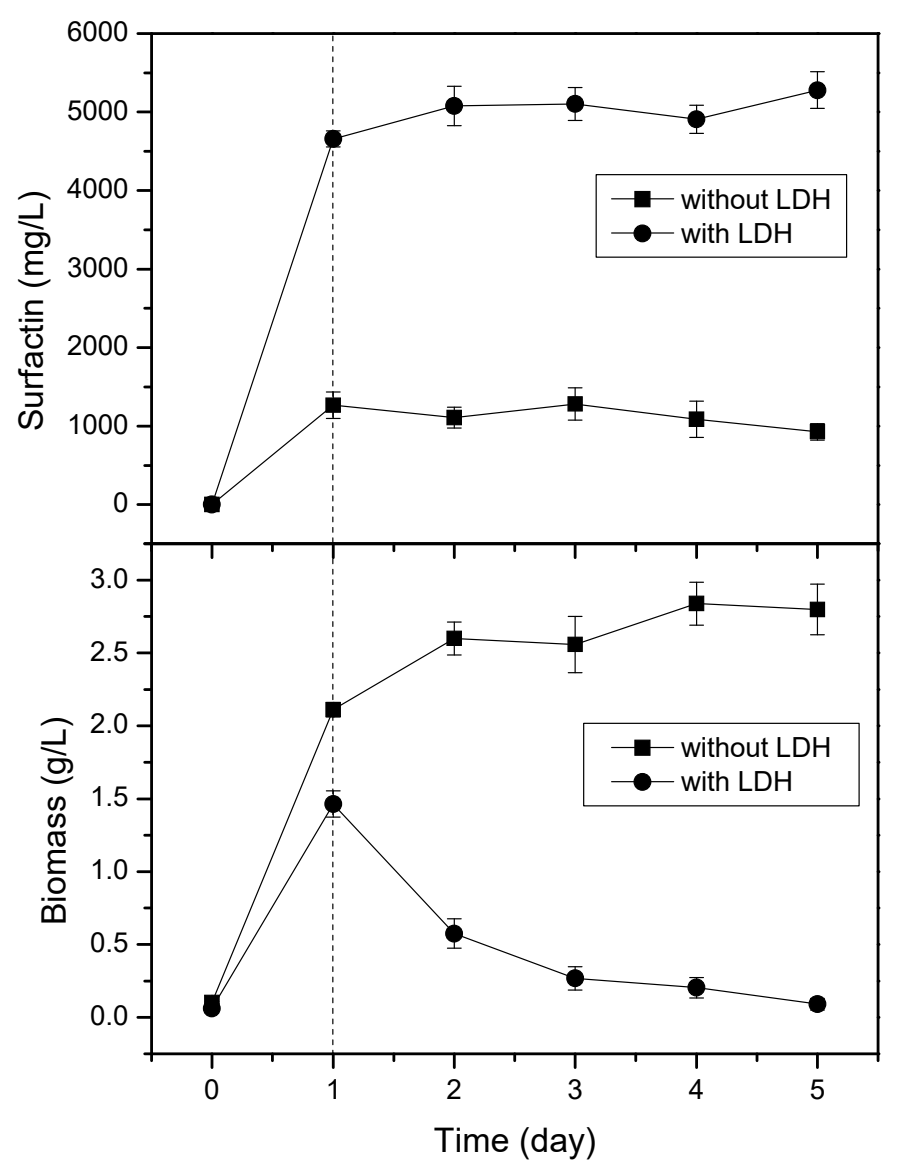

Figure 4. Time courses of surfactin and biomass production in the presence and absence of $\mathrm{Mg}_{2} \mathrm{Fe}-\mathrm{LDH}$ $(4 \mathrm{~g} / \mathrm{L})$. Error bars indicate the standard deviations from three tests.

Figure 5A,B present microscopy images of the morphologies of the cells grown in the presence of the LDH. In the culture medium lacking the LDH, the cells had a short and rod-like morphology from day 1 to day 3 of culturing. By the fifth day, some cells became slenderer than the original short-rod cells. In contrast, in the culture medium incorporating the $\mathrm{LDH}$, the cells grew in a short-rod shape on the first day, but, by the third day, most of the cells had decayed and shrunk, with many endospores present. By the fifth day, almost none of the cells were evident in the broth, with only some spores remaining in the culture. This observation is consistent with the amounts of cells measured in the study. Therefore, the addition of LDH did inhibit the growth of cells during the cell growth phase, but it also enhanced the production of surfactin. Accordingly, in addition to the high surfactin yield of the culture incorporating the $\mathrm{LDH}$, an extremely high productivity also ensued. Because of the lower number of cells, not only was the specific production elevated, the carbon source conversion to surfactin was also enhanced and provided a high carbon yield. 
(Day 1$)$

(A)

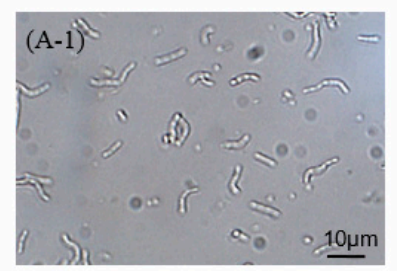

(B)

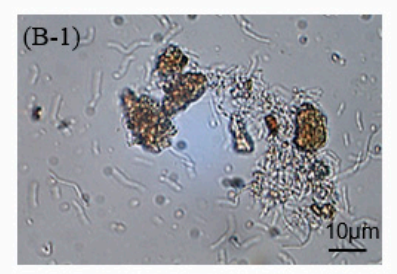

(Day 3)
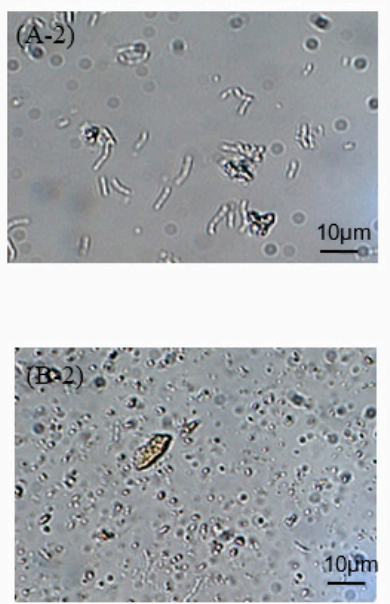

(Day 5)
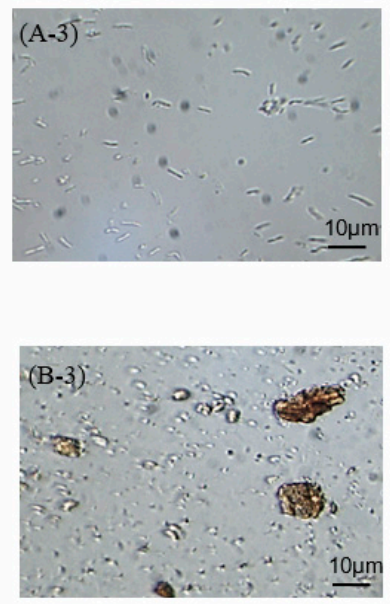

Figure 5. Optical microscopy images of B. subtilis ATCC 21332 growth, taken after various numbers of cultivation days; (A) in the absence of any $\mathrm{LDH} ;(\mathbf{B})$ in the presence of $\mathrm{Mg}_{2} \mathrm{Fe}-\mathrm{LDH}$.

\subsection{Comparison of Surfactin Production}

Table 1 compares the surfactin production in this present study with those reported previously in the literature. Four factors characterize surfactin production in these bioprocesses in terms of their efficiency for fermentation on industrial scale: the surfactin yield, the carbon yield, the productivity, and the specific production. Due to the variation on surfactin quantification, the surfactin assays, such as HPLC, surface tensions, and acid precipitation, were also listed. As evident in Table 1, the addition of $\mathrm{Mg}_{2} \mathrm{Fe}-\mathrm{LDH}$ had a unique effect in promoting surfactin production. Historically, surfactin production has improved gradually from an original yield of less than $1000 \mathrm{mg} / \mathrm{L}$ two decades ago to approximately 2000 to $3000 \mathrm{mg} / \mathrm{L}$ recently. When using this present approach, the yield of surfactin after the addition of $\mathrm{Mg}_{2} \mathrm{Fe}-\mathrm{LDH}$ was enhanced significantly, to greater than $5000 \mathrm{mg} / \mathrm{L}$. Furthermore, the addition of $\mathrm{Mg}_{2} \mathrm{Fe}-\mathrm{LDH}$ ensured that the carbon source mostly flowed to surfactin production. Indeed, the carbon source yield was approximately $52.8 \%$. This high carbon yield characterizes a surfactin production process with a highly efficient use of the raw material. In addition, the presence of $\mathrm{Mg}_{2} \mathrm{Fe}-\mathrm{LDH}$ caused the surfactin yield to reach $4660 \mathrm{mg} / \mathrm{L}$ after one day of culturing; that is, the productivity was $4660 \mathrm{mg} / \mathrm{L}$, a remarkably high value as compared in the literature. In addition, because the number of cells decreased in the presence of $\mathrm{Mg}_{2} \mathrm{Fe}-\mathrm{LDH}$, the smaller amount of biomass and the higher surfactin yield led to a specific yield of $3.19 \mathrm{~g} / \mathrm{g}$ DCW. The addition of $\mathrm{Mg}_{2} \mathrm{Fe}-\mathrm{LDH}$ in B. subtilis submerged cultivation provided a high carbon yield, high productivity, and high specific production of surfactin; such a high efficiency appears well suited to industrial applications.

At the beginning of our approach, the change of $\mathrm{Mg}_{2} \mathrm{Al}-\mathrm{LDH}$ to $\mathrm{Mg}_{2} \mathrm{Fe}-\mathrm{LDH}$ was due to the practical need in agricultural applications, where the aluminum salt is prohibited from field tests. However, to our surprise, the replacement of additive to $\mathrm{Mg}_{2} \mathrm{Fe}-\mathrm{LDH}$ did give an extraordinarily high surfactin production. Due to this effect, the three critical characteristics affecting surfactin production were evaluated. It was found that a high specific surfactin yield, a high productivity, and a high carbon yield could be obtained in the presence of the $\mathrm{Mg}_{2} \mathrm{Fe}-\mathrm{LDH}$. To explain the difference between $\mathrm{Mg}_{2} \mathrm{Fe}-\mathrm{LDH}$ and $\mathrm{Mg}_{2} \mathrm{Al}-\mathrm{LDH}$ additions, the effect of the $\mathrm{Mg}_{2} \mathrm{Fe}-\mathrm{LDH}$ addition with the leaking iron trace element in the culture was the possible reason for this highly efficient surfactin production. To decipher the cause of the extraordinarily high stimulatory effect of $\mathrm{Mg}_{2} \mathrm{Fe}-\mathrm{LDH}$, the following considerations might be taken into account. In some previous studies, ferric ions have been found to serve as trace element stimulators, with an excellent ability to promote surfactin production $[21,43,44]$. In addition, the use of pristine $\mathrm{Mg}_{2} \mathrm{Al}-\mathrm{LDH}$ has been claimed to enhance surfactin production as a result of its toxicity toward the cells [33]. Accordingly, the presence of $\mathrm{Mg}_{2} \mathrm{Fe}-\mathrm{LDH}$ was expected to not only inhibit cell growth and promote surfactin production (similar to the behavior of $\mathrm{Mg}_{2} \mathrm{Al}-\mathrm{LDH}$ ) 
but also to slowly release some iron salts to serve as trace elements in the medium, thereby also improving the surfactin production. The higher production obtained using $\mathrm{Mg}_{2} \mathrm{Fe}-\mathrm{LDH}$, compared with that of $\mathrm{Mg}_{2} \mathrm{Al}-\mathrm{LDH}$, might be due to the synergistic effect of the $\mathrm{Mg}_{2} \mathrm{Fe}-\mathrm{LDH}$ crystalline structure and the trace iron salts in the medium, with both combining to promote surfactin production to such a high level.

Table 1. Various approaches used for surfactin production.

\begin{tabular}{|c|c|c|c|c|c|c|}
\hline Approach & $\begin{array}{l}\text { Yield }^{a} \\
(\mathrm{mg} / \mathrm{L})\end{array}$ & $\begin{array}{c}\text { Carbon Yield } \\
\text { (g/g carbon source) }\end{array}$ & $\begin{array}{l}\text { Productivity }{ }^{\mathrm{b}} \\
\text { (mg/L/day) }\end{array}$ & $\begin{array}{l}\text { Specific production }{ }^{c} \\
(\mathrm{~g} / \mathrm{g} \text { DCW })\end{array}$ & $\begin{array}{c}\text { Surfactin } \\
\text { Quantification }\end{array}$ & Ref. \\
\hline Iron addition \& product in foam & 800 & 0.02 & - & 0.615 & Acid precipitate & [45] \\
\hline Peat hydrolysate medium & 160 & 0.004 & 160 & 0.208 & HPLC & [46] \\
\hline Aqueous two phase & 350 & 0.07 & 350 & - & Surface tensions & [47] \\
\hline Optimized medium & 760 & 0.021 & & - & Surface tensions & [19] \\
\hline Optimized nitrogen source & 439 & 0.015 & 219 & 0.075 & HPLC & [18] \\
\hline Recombinant strain & 350 & 0035 & 350 & - & HPLC & [48] \\
\hline Strain mutation and product in foam & 562 & 0.014 & 562 & 0.323 & Surface tensions & [16] \\
\hline Iron-enriched medium & 3500 & 0.088 & - & - & HPLC & [43] \\
\hline Optimized iron supplement & 3000 & - & - & 0.162 & HPLC & [21] \\
\hline Activated carbon addition & 3600 & 0.09 & 1200 & - & HPLC & [17] \\
\hline Optimized trace element & 3340 & 0.084 & - & - & HPLC & [49] \\
\hline $\mathrm{Mn}^{2+}$ addition & 2600 & 0.065 & & 0.289 & HPLC & [20] \\
\hline $\mathrm{Mg}_{2} \mathrm{Al} \mathrm{LDH}$ addition & 3789 & 0.379 & - & - & HPLC & This study \\
\hline $\mathrm{Mg}_{2} \mathrm{Fe} \mathrm{LDH}$ addition & 5280 & 0.528 & 4660 & 3.19 & HPLC & This study \\
\hline
\end{tabular}

${ }^{a}$ Maximum yield in whole culture. ${ }^{b}$ Maximum productivity in whole culture. ${ }^{c}$ Specific production when reaching maximum yield.

\section{Conclusions}

We investigated the effects of LDHs on the production of biomass and surfactin in a B. subtilis ATCC 21332 culture. The highest yield of surfactin $(5280 \mathrm{mg} / \mathrm{L})$ was obtained after 5 days of cultivation in the presence of $4 \mathrm{~g} / \mathrm{L} \mathrm{Mg}_{2} \mathrm{Fe}-\mathrm{LDH}$. This study demonstrated that LDHs have potential for use as additives to enhance the production of surfactin in B. subtilis ATCC 21332. Furthermore, microscopy revealed the inhibition of cell growth in the presence of the LDH, suggesting an efficient process for the production of surfactin through greater conversion of the carbon source.

Supplementary Materials: The following are available online at http://www.mdpi.com/2073-4352/9/7/355/s1, Figure S1: Typical surfactin standard chromatogram in HPLC showing surfactin isoform A-F.

Author Contributions: Data curation and methodology, P.-H.C. and S.-Y.L., conceptualization, writing-original draft preparation; writing—review and editing, project administration, T.-Y.J. and Y.-C.L.

Funding: This study was supported by research grants from the National Science Council of Taiwan, R.O.C. (grant nos. NSC 101-2221-E-005-061 and 106-2113-M-039-007), and China Medical University (grant no. CMU 107-N-22).

Acknowledgments: We thank Wei Yu-Hong of Yuan Ze University for sharing the strain B. subtilis ATCC 21332.

Conflicts of Interest: The authors declare no conflict of interest.

\section{References}

1. Maier, R.M.; Soberon-Chavez, G. Pseudomonas aeruginosa rhamnolipids: Biosynthesis and potential applications. Appl. Microbiol. Biotechnol. 2000, 54, 625-633. [CrossRef] [PubMed]

2. Kim, H.S.; Yoon, B.D.; Choung, D.H.; Oh, H.M.; Katsuragi, T.; Tani, Y. Characterization of a biosurfactant, mannosylerythritol lipid produced from Candida sp. SY16. Appl. Microbiol. Biotechnol. 1999, 52, 713-721. [CrossRef] [PubMed]

3. Banat, I.M. Biosurfactants production and possible uses in microbial enhanced oil recovery and oil pollution remediation: A review. Bioresour. Technol. 1995, 51,1-12. [CrossRef]

4. Desai, J.D.; Banat, I.M. Microbial production of surfactants and their commercial potential. Microbiol. Mol. Biol. Rev. 1997, 61, 47-64. [PubMed]

5. Mukherjee, A.K.; Das, K. Microbial surfactants and their potential applications: An overview. Adv. Exp. Med. Biol. 2010, 672, 54-64. [PubMed] 
6. Mulligan, C.N. Environmental applications for biosurfactants. Environ. Pollut. 2005, 133, 183-198. [CrossRef] [PubMed]

7. Shaligram, N.S.; Singhal, R.S. Surfactin-A review on biosynthesis, fermentation, purification and applications. Food Technol. Biotechnol. 2010, 48, 119-134.

8. Hosono, K.; Suzuki, H. Acylpeptides, the inhibitors of cyclic adenosine $3^{\prime}, 5^{\prime}$-monophosphate phosphodiesterase. I. Purification, physicochemical properties and structures of fatty acid residues. J. Antibiot. 1983, 36, 667-673. [CrossRef] [PubMed]

9. Kakinuma, A.; Hori, M.; Isono, M.; Tamura, G.; Arima, K. Determination of amino acid aequence in surfactin a crystalline peptidelipid surfactant produced by Bacillus subtilis. Agric. Biol. Chem. 1969, 33, 971-972. [CrossRef]

10. Arima, K.; Kakinuma, A.; Tamura, G. Surfactin, a crystalline peptide lipid surfactant produced by Bacillus subtilis: Isolation, characterization and its inhibition of fibrin clot formation. Biochem. Biophys. Res. Commun. 1968, 31, 488-494. [CrossRef]

11. Besson, F.; Peypoux, F.; Michel, G.; Delcambe, L. Identification of antibiotics of iturin group in various strains of Bacillus subtilis. J. Antibiot. 1978, 31, 284-288. [CrossRef] [PubMed]

12. Peypoux, F.; Guinand, M.; Michel, G.; Delcambe, L.; Das, B.C.; Lederer, E. Structure of iturine A, a peptidolipid antibiotic from Bacillus subtilis. Biochemistry 1978, 17, 3992-3996. [CrossRef]

13. Vanittanakom, N.; Loeffler, W.; Koch, U.; Jung, G. Fengycin-A novel antifungal lipopeptide antibiotic produced by Bacillus subtilis F-29-3. J. Antibiot. 1986, 39, 888-901. [CrossRef]

14. Liao, J.H.; Chen, P.Y.; Yang, Y.L.; Kan, S.C.; Hsieh, F.C.; Liu, Y.C. Clarification of the antagonistic effect of the lipopeptides produced by Bacillus amyloliquefaciens BPD1 against Pyricularia oryzae via in situ MALDI-TOF IMS analysis. Molecules 2016, 21, 1670. [CrossRef] [PubMed]

15. Abdel-Mawgoud, A.M.; Aboulwafa, M.M.; Hassouna, N.A. Characterization of surfactin produced by Bacillus subtilis isolate BS5. Appl. Biochem. Biotechnol. 2008, 150, 289-303. [CrossRef] [PubMed]

16. Mulligan, C.N.; Chow, T.Y.-K.; Gibbs, B.F. Enhanced biosurfactant production by a mutant Bacillus subtilis strain. Appl. Microbiol. Biotechnol. 1989, 31, 486-489. [CrossRef]

17. Yeh, M.S.; Wei, Y.H.; Chang, J.S. Enhanced production of surfactin from Bacillus subtilis by addition of solid carriers. Biotechnol. Prog. 2005, 21, 1329-1334. [CrossRef]

18. Davis, D.A.; Lynch, H.C.; Varley, J. The production of surfactin in batch culture by Bacillus subtilis ATCC 21332 is strongly influenced by the conditions of nitrogen metabolism. Enzyme Microb. Technol. 1999, 25, 322-329. [CrossRef]

19. Sen, R. Response surface optimization of the critical media components for the production of surfactin. J. Chem. Technol. Biotechnol. 1997, 68, 263-270. [CrossRef]

20. Wei, Y.-H.; Chu, I.-M. $\mathrm{Mn}^{2+}$ improves surfactin production by Bacillus subtilis. Biotechnol. Lett. 2002, 24, 479-482. [CrossRef]

21. Wei, Y.-H.; Wang, L.-F.; Chang, J.-S. Optimizing iron supplement strategies for enhanced surfactin production with Bacillus subtilis. Biotechnol. Prog. 2004, 20, 979-983. [CrossRef] [PubMed]

22. Cavani, F.; Trifirò, F.; Vaccari, A. Hydrotalcite-type anionic clays: Preparation, properties and applications. Catal. Today 1991, 11, 173-301. [CrossRef]

23. Choy, J.H.; Kwak, S.Y.; Jeong, Y.J.; Park, J.S. Inorganic layered double hydroxides as nonviral vector. Angew. Chem. Int. Ed. 2000, 39, 4041-4045. [CrossRef]

24. Wang, Q.; O'Hare, D. Recent advances in the synthesis and application of layered double hydroxide (LDH) nanosheets. Chem. Rev. 2012, 112, 4124-4155. [CrossRef] [PubMed]

25. Williams, G.R.; O'Hare, D. Towards understanding, control and application of layered double hydroxide chemistry. J. Mater. Chem. 2006, 16, 3065-3074. [CrossRef]

26. Evans, D.G.; Duan, X. Preparation of layered double hydroxides and their applications as additives in polymers, as precursors to magnetic materials and in biology and medicine. Chem. Commun. 2006, 5, 485-496. [CrossRef] [PubMed]

27. Lin, J.-J.; Juang, T.-Y. Intercalation of layered double hydroxides by poly(oxyalkylene)-amidocarboxylates: Tailoring layered basal spacing. Polymer 2004, 45, 7887-7893. [CrossRef]

28. Shau, S.-M.; Juang, T.-Y.; Lin, H.-S.; Huang, C.-L.; Hsieh, C.-F.; Wu, J.-Y.; Jeng, R.-J. Individual graphene oxide platelets through direct molecular exfoliation with globular amphiphilic hyperbranched polymers. Polym. Chem. 2012, 3, 1249-1259. [CrossRef] 
29. Juang, T.-Y.; Chen, Y.-C.; Tsai, C.-C.; Dai, S.A.; Wu, T.-M.; Jeng, R.-J. Nanoscale organic/inorganic hybrids based on self-organized dendritic macromolecules on montmorillonites. Appl. Clay Sci. 2010, 48, 103-110. [CrossRef]

30. Conterosito, E.; Croce, G.; Palin, L.; Pagano, C.; Perioli, L.; Viterbo, D.; Boccaleri, E.; Paul, G.; Milanesio, M. Structural characterization and thermal and chemical stability of bioactive molecule-hydrotalcite (LDH) nanocomposites. Phys. Chem. Chem. Phys. 2013, 15, 13418-13433. [CrossRef]

31. Toson, V.; Conterosito, E.; Palin, L.; Boccaleri, E.; Milanesio, M.; Gianotti, V. Facile intercalation of organic molecules into hydrotalcites by liquid-assisted grinding: Yield optimization by a chemometric approach. Cryst. Growth Des. 2015, 15, 5368-5374. [CrossRef]

32. Choy, J.-H.; Choi, S.-J.; Oh, J.-M.; Park, T. Clay minerals and layered double hydroxides for novel biological applications. Appl. Clay Sci. 2007, 36, 122-132. [CrossRef]

33. Kan, S.-C.; Lee, C.-C.; Hsu, Y.-C.; Peng, Y.-H.; Chen, C.-C.; Huang, J.-J.; Huang, J.-W.; Shieh, C.-J.; Juang, T.-Y.; Liu, Y.-C. Enhanced surfactin production via the addition of layered double hydroxides. J. Taiwan Inst. Chem. Eng. 2017, 80, 10-15. [CrossRef]

34. Delhaize, E.; Ryan, P.R. Aluminum toxicity and tolerance in plants. Plant Physiol. 1995, 107, $315-321$. [CrossRef] [PubMed]

35. Pourhossein, A.; Alizadeh, K. Salt-assisted liquid-liquid extraction followed by high performance liquid chromatography for determination of carvedilol in human plasma. J. Rep. Pharm. Sci. 2018, 7, 79-87.

36. Kuthati, Y.; Kankala, R.K.; Lee, C.-H. Layered double hydroxide nanoparticles for biomedical applications: Current status and recent prospects. Appl. Clay Sci. 2015, 112-113, 100-116. [CrossRef]

37. Mishra, G.; Dash, B.; Pandey, S. Layered double hydroxides: A brief review from fundamentals to application as evolving biomaterials. Appl. Clay Sci. 2018, 153, 172-186. [CrossRef]

38. Aisawa, S.; Takahashi, S.; Ogasawara, W.; Umetsu, Y.; Narita, E. Direct intercalation of amino acids into layered double hydroxides by coprecipitation. J. Solid State Chem. 2001, 162, 52-62. [CrossRef]

39. Khan, A.I.; O'Hare, D. Intercalation chemistry of layered double hydroxides: Recent developments and applications. J. Mater. Chem. 2002, 12, 3191-3198. [CrossRef]

40. Rives, V. Characterisation of layered double hydroxides and their decomposition products. Mater. Chem. Phys. 2002, 75, 19-25. [CrossRef]

41. Rives, V.; Ulibarri, M.A. Layered double hydroxides (LDH) intercalated with metal coordination compounds and oxometalates. Coord. Chem. Rev. 1999, 181, 61-120. [CrossRef]

42. Long, X.; Wang, Z.; Xiao, S.; An, Y.; Yang, S. Transition metal based layered double hydroxides tailored for energy conversion and storage. Mater. Today 2016, 19, 213-226. [CrossRef]

43. Wei, Y.-H.; Chu, I.-M. Enhancement of surfactin production in iron-enriched media by Bacillus subtilis ATCC 21332. Enzyme Microb. Technol. 1998, 22, 724-728. [CrossRef]

44. Wei, Y.-H.; Wang, L.-F.; Chang, J.-S.; Kung, S.-S. Identification of induced acidification in iron-enriched cultures of Bacillus subtilis during biosurfactant fermentation. J. Biosci. Bioeng. 2003, 96, 174-178. [CrossRef]

45. Cooper, D.G.; Macdonald, C.R.; Duff, S.J.; Kosaric, N. Enhanced production of surfactin from Bacillus subtilis by continuous product removal and metal cation additions. Appl. Environ. Microbiol. 1981, 42, 408-412. [PubMed]

46. Sheppard, J.D.; Mulligan, C.N. The production of surfactin by Bacillus subtilis grown on peat hydrolysate. Appl. Microbiol. Biotechnol. 1987, 27, 110-116. [CrossRef]

47. Drouin, C.M.; Cooper, D.G. Biosurfactants and aqueous two-phase fermentation. Biotechnol. Bioeng. 1992, 40, 86-90. [CrossRef] [PubMed]

48. Ohno, A.; Ano, T.; Shoda, M. Production of a lipopeptide antibiotic surfactin with recombinant Bacillus subtilis. Biotechnol. Lett. 1992, 14, 1165-1168. [CrossRef]

49. Wei, Y.-H.; Lai, C.-C.; Chang, J.-S. Using Taguchi experimental design methods to optimize trace element composition for enhanced surfactin production by Bacillus subtilis ATCC 21332. Process Biochem. 2007, 42, 40-45. [CrossRef]

(C) 2019 by the authors. Licensee MDPI, Basel, Switzerland. This article is an open access article distributed under the terms and conditions of the Creative Commons Attribution (CC BY) license (http://creativecommons.org/licenses/by/4.0/). 